\title{
Synthesis of Thin Films of Sulfides of Cadmium, Lead and Copper by Chemical Bath Deposition
}

\author{
Armando Gregorio Rojas Hernández and \\ S. Jesus Castillo \\ Additional information is available at the end of the chapter \\ http://dx.doi.org/10.5772/66751
}

\begin{abstract}
The goal of this chapter is to present three kind of thin films for the materials, done by Chemical Bath Deposition technique, the materials are CdS, PbS and CuS. The characterization has been diversified, but consisting mainly $\mathrm{X}$-ray Diffraction (XRD) giving hexagonal, cubic and amorphous structures of $\mathrm{CdS}, \mathrm{PbS}$ and $\mathrm{CuS}$ respectively. The Raman dispersion let to found the characteristics peaks of vibration, one for the CdS located on $300.7 \mathrm{~cm}^{-1}$, three for PbS and two more for the CuS. We use X-rays Photoelectron Spectroscopy to formalize the chemical composition analysis, from this analysis we could to proof the high purity of the chemical bath deposition method in the materials preparation. We used UV-Vis Spectroscopy to determine simple optical responses, getting the biggest transmittances of $72 \%$ for $\mathrm{CdS}, 45 \%$ for $\mathrm{PbS}$, and $80 \%$ for CuS, and direct energy band gaps of $2.47 \mathrm{eV}$ for $\mathrm{CdS}, 1.78 \mathrm{eV}$ for $\mathrm{CuS}$ as ground and with thermic annealing $2.45 \mathrm{eV}$ which is believed result of amorphous to crystalline morphology changes, the indirect bandgap 0.94 $\mathrm{eV}$ is measured too. The AFM given information about the surface morphology and roughness, Scanning Electron Microscopy (SEM) micrography shows the polycrystallinity nature of the CuS including the smooth.
\end{abstract}

Keywords: thin films, semiconductors, solar cells, chalcogenides, CBD

\section{Introduction}

Lead sulfide (PbS) and cadmium sulfide (CdS) are two semiconductors studied since time ago, their combined research has around one century and the direct band gap for $\mathrm{PbS}$ is around 0.37 $\mathrm{eV}$ at $300 \mathrm{~K}$ [1-10]. The PbS is mainly used as an infrared detector in various fields has been used mainly as an infra-red detector in another diverse field [11-15]. On the other hand, the $\mathrm{CdS}$ material shows a direct band gap between 2.42 and $2.53 \mathrm{eV}$ [16-25]. The CdS material was used as a pigment as well as for solar cells optical window; cadmium sulfide is a semiconductor 
II-VI type which is mainly useful in optoelectronic devices and some researchers reported that it has low conductivity of $10.8(\Omega \mathrm{cm})^{-1}$.

Lead sulfide has a cubic crystallographic structure, while cadmium sulfide can be cubic or hexagonal, basically. Here we also discuss some features of copper sulfide (CuS) semiconductor film. These materials are mostly found in amorphous nature with poor crystallinity tending to nanocrystals. Some reports showed the possibility of converting CuS films into the chalcocite phase by mean copper atomic implanting; in reference [26] the authors reported an indirect band gap of $1.28 \mathrm{eV}$ for CuS. CuS is used in various applications such as ion sensitive electrodes and photothermal conversion solar controllers [27, 28].

\section{Synthesis of the thin films}

$\mathrm{CdS}$ thin films were deposited on microscope glass substrates, immersed into a $100 \mathrm{ml}$ beaker containing a solution mixture of $31 \mathrm{ml}$ of deionized water, $4 \mathrm{ml}$ of $0.1 \mathrm{M}$ cadmium nitrate tetrahydrate $\left(\mathrm{Cd}\left(\mathrm{NO}_{3}\right)_{2} 4 \mathrm{H}_{2} \mathrm{O}\right), 5 \mathrm{ml}$ of $0.5 \mathrm{M}$ glycine $\left(\mathrm{NH}_{2} \mathrm{CH}_{2} \mathrm{COOH}\right), 2 \mathrm{ml}$ of $\mathrm{pH} 11$ buffer, 5 $\mathrm{ml}$ of $1 \mathrm{M}$ thiourea $\left(\left(\mathrm{NH}_{2}\right)_{2} \mathrm{CS}\right)$ and finally in the mixture solution of $60 \mathrm{ml}$ of deionized water was added in order to increase the reaction volume. The mix of solutions was placed in a thermal reservoir maintained at $70^{\circ} \mathrm{C}$ for $10 \mathrm{~min}$ and a homogeneous $\mathrm{CdS}$ film with a direct band gap of $2.47 \mathrm{eV}$ was obtained.

$\mathrm{PbS}$ thin films were obtained by sequentially adding $5 \mathrm{ml}$ of lead acetate $(0.5 \mathrm{M})$ and $5 \mathrm{ml}$ of sodium hydroxide $(2 \mathrm{M}), 6 \mathrm{ml}$ of thiourea $(1 \mathrm{M})$ and $2 \mathrm{ml}$ of triethanolamine $(1 \mathrm{M})$ in mixture solution and finally in the solution, $82 \mathrm{ml}$ of ionized water is added. After stirring the mixture solution, in order to homogenize the mixture, the reaction mixture was placed in a thermal source at $70{ }^{\circ} \mathrm{C}$ for $5 \mathrm{~min}$.

$\mathrm{CuS}$ thin films were deposited in glass substrates obtained from a solution by adding $2 \mathrm{ml}$ of dilute copper nitrate $(0.1 \mathrm{M})$ into $31 \mathrm{ml}$ of deionized water and then adding sequentially $2 \mathrm{ml}$ of barium hydroxide $(0.01 \mathrm{M}), 2 \mathrm{ml}$ of triethanolamine $(1 \mathrm{M}), 4 \mathrm{ml}$ of thiourea $(1 \mathrm{M})$ and finally 19 $\mathrm{ml}$ of deionized water. The determined reaction time was $20 \mathrm{~min}$. Using the process, we are able to obtained CuS thin films of around $150 \mathrm{~nm}$ thickness, amorphous, weakly adhered and a direct energy band gap of $1.26 \mathrm{eV}$ [9].

Rigaku Ultima III diffractometer with micro-Raman X'Plora BXT40 at 2400T resolution was used to collect the X-ray patterns. The chemical analysis was carried out using an XPS PerkinElmer Phi-5000 model. Transmission spectra were obtained using an Ocean Optics USB4000UV-VIS spectrometer in the $280-850 \mathrm{~nm}$ wavelength range. The surface morphology of the samples was studied by atomic force microscopy (AFM), using a JSPM-4210 scanning probe microscope (JEOL Ltd.), SEM Zeiss SUPRA 40.

This section describes the chemical formulations used to obtain the selected thin films materials such as CdS, PbS and CuS. As can be observed, the used chemical compounds (precursors) are so easy to manipulate and the procedure just consists of adding the ordered aqueous solutions sequentially, heating and waiting for the deposition time.

The following are the chemical formulations to obtain cadmium sulfide (CdS) thin films: 
1. $31 \mathrm{ml}$ of $\mathrm{H}_{2} \mathrm{O}$ (deionized water)

2. $4 \mathrm{ml}$ of $\mathrm{Cd}\left(\mathrm{NO}_{3}\right)_{2} 4 \mathrm{H}_{2} \mathrm{O}, 0.1 \mathrm{M}$

3. $5 \mathrm{ml}$ of glycine, $\left(\mathrm{NH}_{2} \mathrm{CH}_{2} \mathrm{COOH}\right), 0.1 \mathrm{M}$

4. $2 \mathrm{ml}$ of buffer $\mathrm{pH} 11,\left[\mathrm{NH}_{4} \mathrm{OH} / \mathrm{NH}_{4} \mathrm{Cl}\right]$

5. $5 \mathrm{ml}$ of thiourea, $\mathrm{NH}_{2} \mathrm{CSNH}_{2}, 1 \mathrm{M}$

6. $13 \mathrm{ml}$ of $\mathrm{H}_{2} \mathrm{O}$ (water until complete $60 \mathrm{ml}$ )

7. $10 \mathrm{~min}$ at $70^{\circ} \mathrm{C}$

The following are the chemical formulations to obtain lead sulfide (PbS) thin films:

1. $5 \mathrm{ml}$ of lead acetate, $\mathrm{Pb}\left(\mathrm{CH}_{2} \mathrm{COO}\right)_{2}, 0.5 \mathrm{M}$

2. $5 \mathrm{ml}$ of sodium hydroxide $(\mathrm{NaOH}), 2 \mathrm{M}$

3. $6 \mathrm{ml}$ of thiourea $1 \mathrm{M}$

4. $2 \mathrm{ml}$ of triethanolamine $\left(\mathrm{OHCH}_{2} \mathrm{CH}_{2}\right)_{3} \mathrm{~N}, 1 \mathrm{M}$

5. $82 \mathrm{ml}$ of $\mathrm{H}_{2} \mathrm{O}$ (water until complete $100 \mathrm{ml}$ )

6. $5 \mathrm{~min}$ at $70^{\circ} \mathrm{C}$ and $5 \mathrm{~min}$ at $75^{\circ} \mathrm{C}$

The following are the chemical formulations to obtain copper sulfide (CuS) thin films:

1. $31 \mathrm{ml}$ of $\mathrm{H}_{2} \mathrm{O}$ (deionized water)

2. $2 \mathrm{ml}$ of $\mathrm{Cu}\left(\mathrm{NO}_{3}\right), 0.1 \mathrm{M}$

3. $2 \mathrm{ml}$ of $\mathrm{Ba}(\mathrm{OH})_{2}, 0.01 \mathrm{M}$

4. $2 \mathrm{ml}$ of triethanolamine $\left(\mathrm{OHCH}_{2} \mathrm{CH}_{2}\right)_{3} \mathrm{~N}, 1 \mathrm{M}$

5. $4 \mathrm{ml}$ of thiourea $1 \mathrm{M}$

6. $19 \mathrm{ml}$ of deionized $\mathrm{H}_{2} \mathrm{O}$ (water until complete $60 \mathrm{ml}$ )

7. $20 \mathrm{~min}$ at $55^{\circ} \mathrm{C}$

8. The obtained amorphous film was then thermal annealed at $180^{\circ} \mathrm{C}$ for $20 \mathrm{~min}$

\section{Results}

The first characterizations to present are X-ray diffraction patterns for the thin films of materials ( $\mathrm{CdS}, \mathrm{PbS}$ and $\mathrm{CuS}$ ) as ground and $\mathrm{CuS}$ thermal annealed (see Figure 1). Figure 1 shows the precise labels for each film. CdS PDF \# 02-0563, PbS PDF \# 65-9496 and CuS amorphous.

The Raman dispersion characterizations were carried out using a laser with a wavelength of $532 \mathrm{~nm}$. Figure 2 shows a typical Raman signal for CdS [29], the Raman spectrum is noisy, but an adjustment was carried out in order to smooth. 


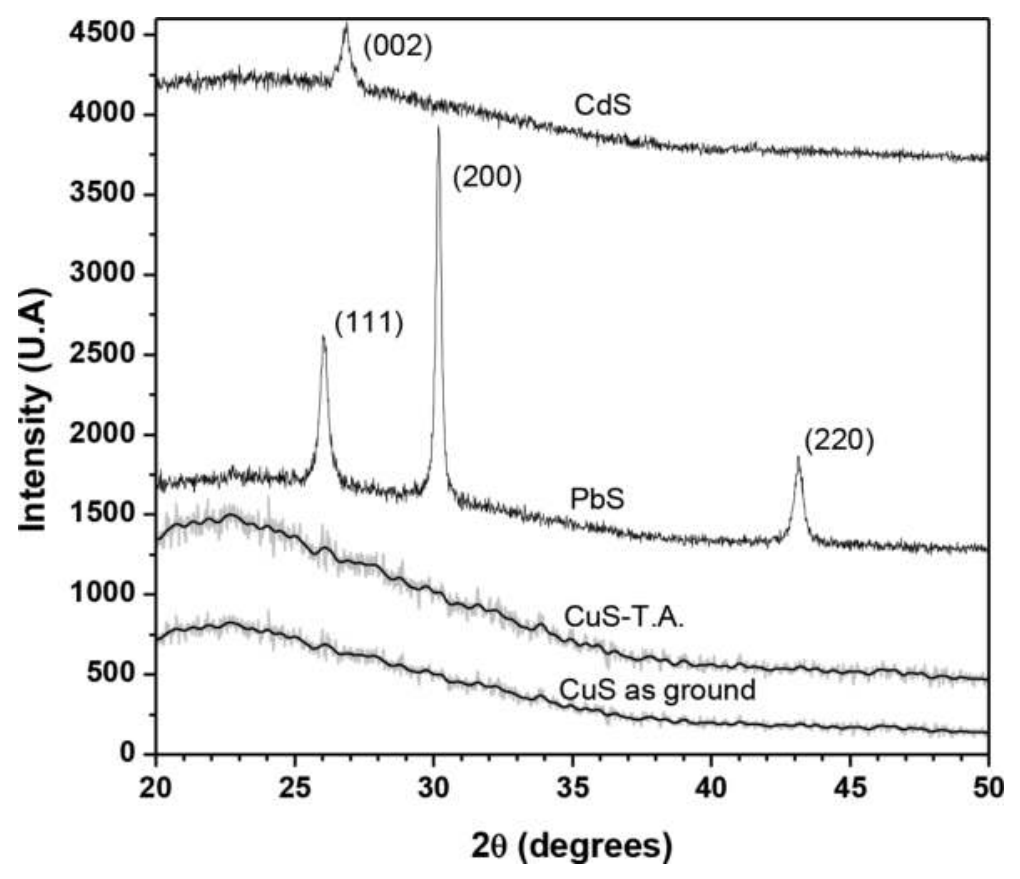

Figure 1. XRD patterns for the synthesized CdS, PbS and CuS films, including a CuS film with thermal annealing.

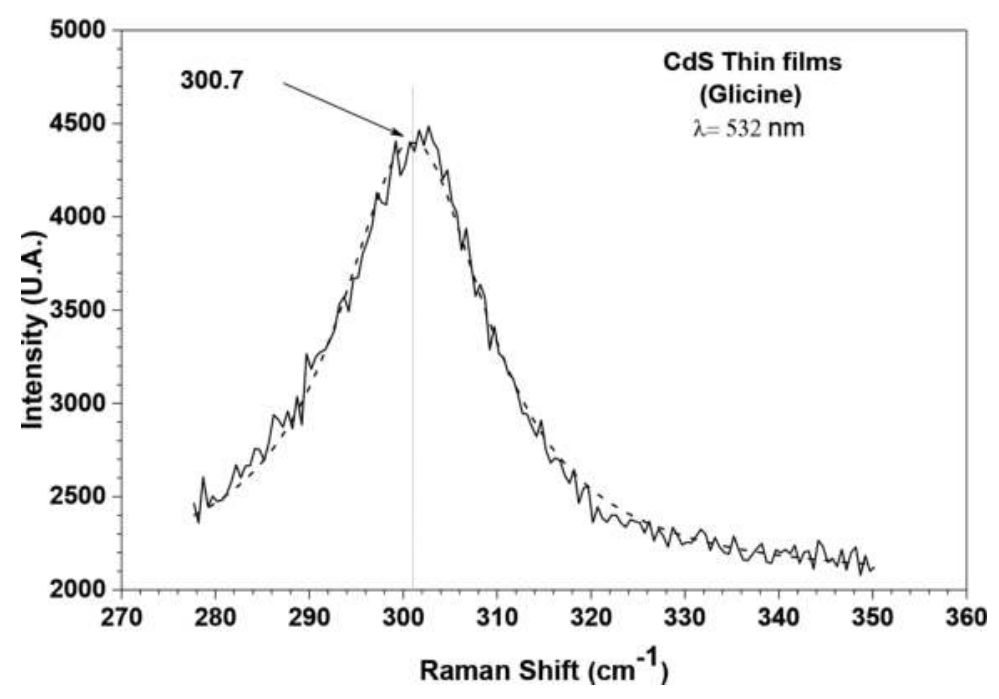

Figure 2. Raman spectrum for CdS thin film prepared by chemical bath deposition at $70^{\circ} \mathrm{C}$ for $10 \mathrm{~min}$. 
For the PbS thin film, the Raman spectrum shows three more intense signals, located in 201.6, 319.9 and $449.07 \mathrm{~cm}^{-1}$ (see Figure 3). Also a laser of $532 \mathrm{~nm}$ wavelength was used to obtain the Raman spectrum.

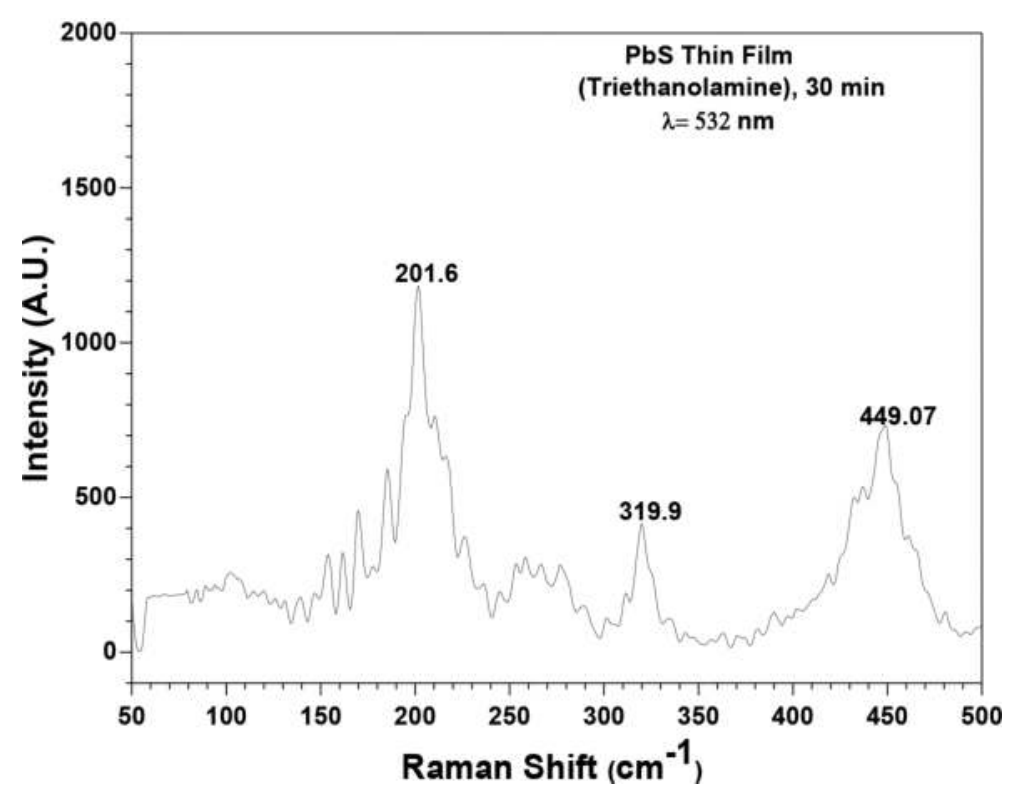

Figure 3. Raman spectrum for $\mathrm{PbS}$ thin film prepared by chemical bath deposition at $75^{\circ} \mathrm{C}$ for $5 \mathrm{~min}$.

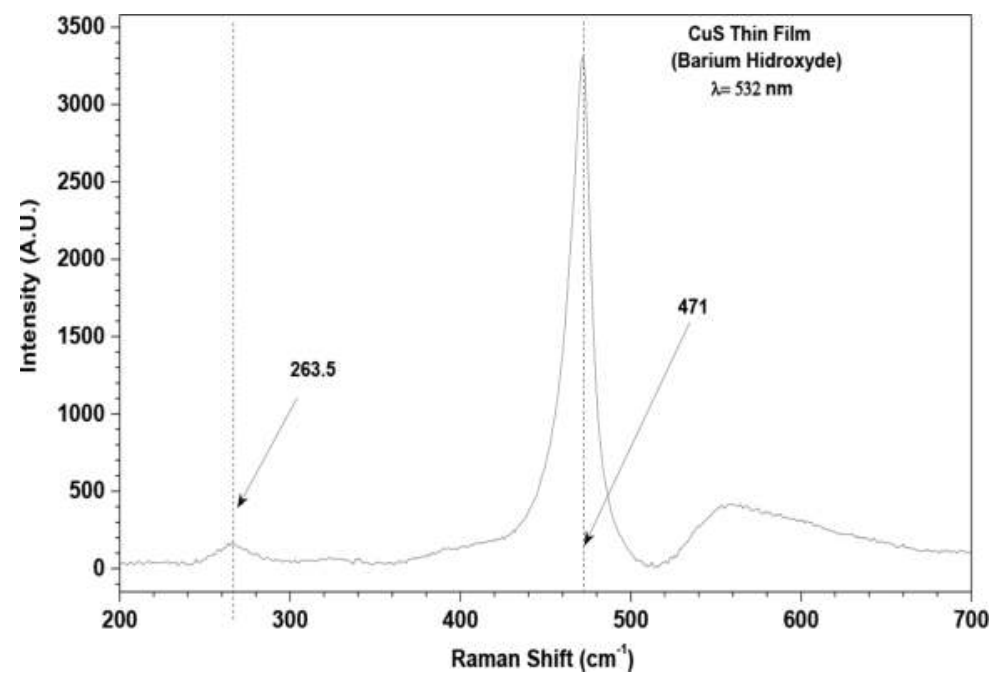

Figure 4. Raman spectrum for CuS thin film prepared by chemical bath deposition at $55^{\circ} \mathrm{C}$ for $20 \mathrm{~min}$. 
XPS

\begin{tabular}{|c|c|c|c|c|c|c|}
\hline \multirow[t]{2}{*}{ Label } & \multicolumn{2}{|c|}{ CdS } & \multicolumn{2}{|c|}{$\mathrm{PbS}$} & \multicolumn{2}{|c|}{ CuS } \\
\hline & Energy level & $\mathrm{eV}$ & Energy level & $\mathrm{eV}$ & Energy level & $\mathrm{eV}$ \\
\hline a & Cd MNN (Auger) & 882.32 & O KLL (Auger) & 749.31 & $\mathrm{Cu} 2 \mathrm{p} 1$ & 954.6 \\
\hline $\mathrm{b}$ & O KLL (Auger) & 745.42 & $\mathrm{~Pb} 4 \mathrm{p} 3$ & 647.66 & $\mathrm{Cu} 2 \mathrm{p} 3$ & 933.15 \\
\hline c & $\mathrm{Cd} 3 \mathrm{p} 1$ & 655.44 & $\mathrm{O} 1 \mathrm{~s}$ & 536.17 & O KLL (Auger) & 743.58 \\
\hline $\mathrm{d}$ & $\mathrm{Cd} 3 \mathrm{p} 3$ & 620.19 & $\mathrm{~Pb} 4 \mathrm{~d} 3$ & 438.41 & $\mathrm{O} 1 \mathrm{~s}$ & 532.28 \\
\hline e & O 1s & 534.11 & $\mathrm{~Pb} 4 \mathrm{~d} 5$ & 416.89 & - & 416.89 \\
\hline $\mathrm{f}$ & $\mathrm{Cd} 3 \mathrm{~d} 3$ & 414.83 & $\mathrm{C} 1 \mathrm{~s}$ & 287.77 & Cu LMM (Auger) & 336.53 \\
\hline g & $\mathrm{Cd} 3 \mathrm{~d} 5$ & 407.05 & S 2p3 & 164.6 & $\mathrm{C} 1 \mathrm{~s}$ & 285.71 \\
\hline $\mathrm{h}$ & $\mathrm{C} 1 \mathrm{~s}$ & 285.71 & $\mathrm{~Pb} 4 \mathrm{f} 5$ & 146.97 & $\mathrm{Cl} 2 \mathrm{~s}$ & 264.19 \\
\hline $\mathrm{i}$ & $\mathrm{S} 2 \mathrm{~s}$ & 227.1 & $\mathrm{~Pb} 4 \mathrm{f} 7$ & 139.19 & $S 2 p$ & 225.045 \\
\hline j & $S 2 p$ & 164.6 & $\mathrm{~Pb} 5 \mathrm{~d} 5$ & 23.58 & Si 2s & 199.63 \\
\hline k & $\mathrm{Cd} 4 \mathrm{~d} 5$ & 13.96 & - & & $\mathrm{Cu} 3 \mathrm{~s}$ & 162.54 \\
\hline 1 & - & & - & & Si $2 p$ & 123.39 \\
\hline $\mathrm{m}$ & - & & - & & $\mathrm{Cu} 3 \mathrm{p} 3$ & 76.46 \\
\hline
\end{tabular}

Table 1. Main chemical composition for three thin films elaborated by chemical bath deposition and their binding energies.

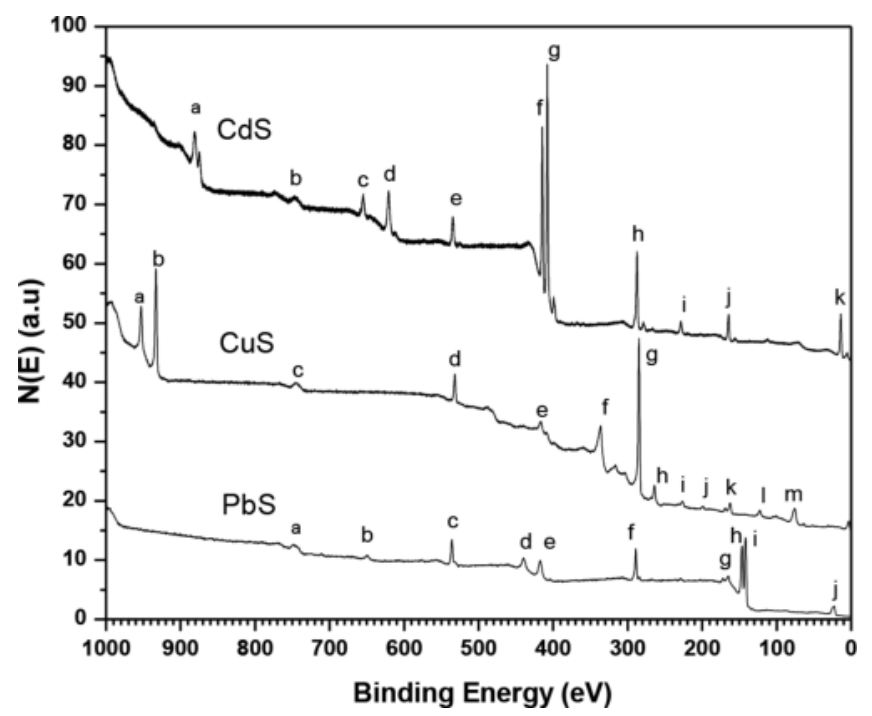

Figure 5. XPS spectra for our three compounds, PbS, CdS and CuS thin films. These plots confirm the chemical composition the obtained materials. 
Raman spectrum for as ground CuS thin film (see Figure 4) shows two well-defined signals or dispersions at 263.5 and $471 \mathrm{~cm}^{-1}$.

The next characterization is carried out by X-ray photoelectron spectroscopy; at this stage, it is possible to determine the chemical composition for the grown materials: CdS thin film, PbS

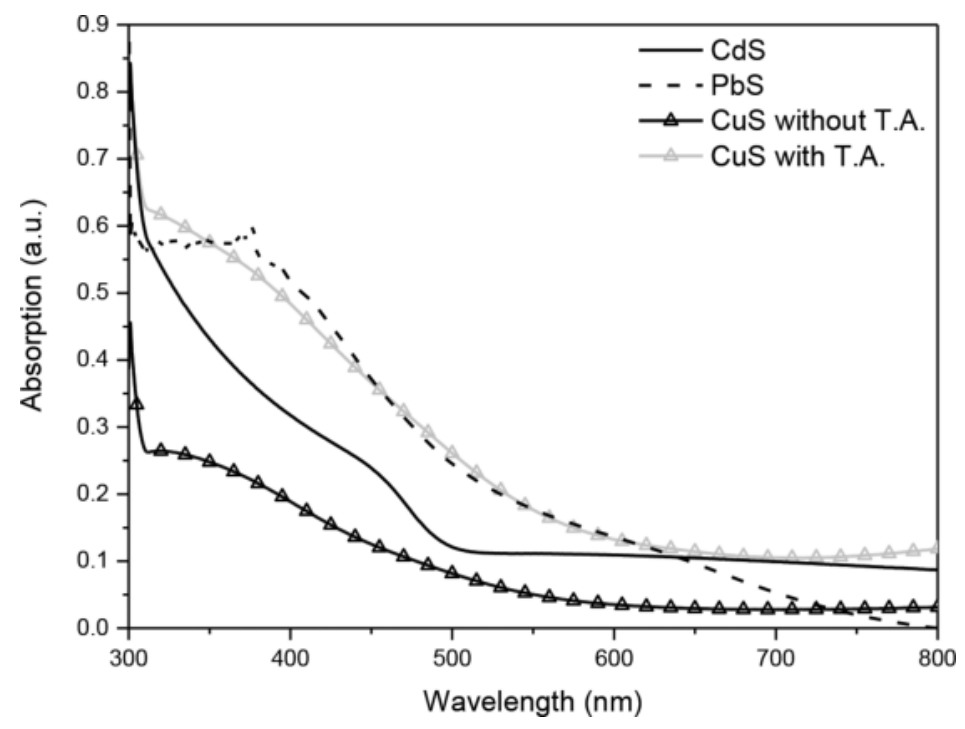

Figure 6. Optical absorption responses for the indicated thin films of $\mathrm{CdS}, \mathrm{PbS}$ and $\mathrm{CuS}$ as ground and CuS thermal annealed.

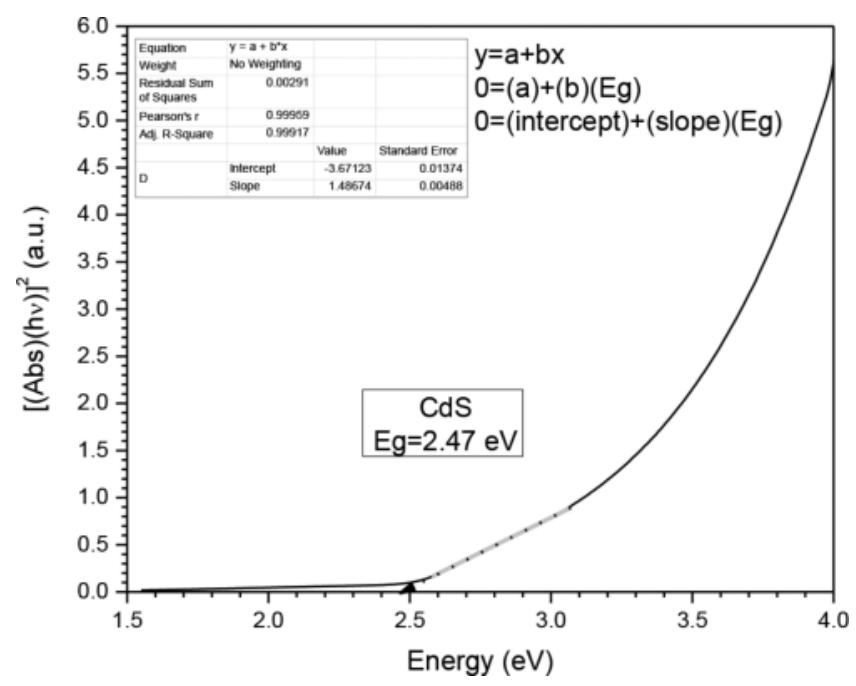

Figure 7. The linear adjustment for the projected CdS thin film with a direct band gap of $2.47 \mathrm{eV}$. 


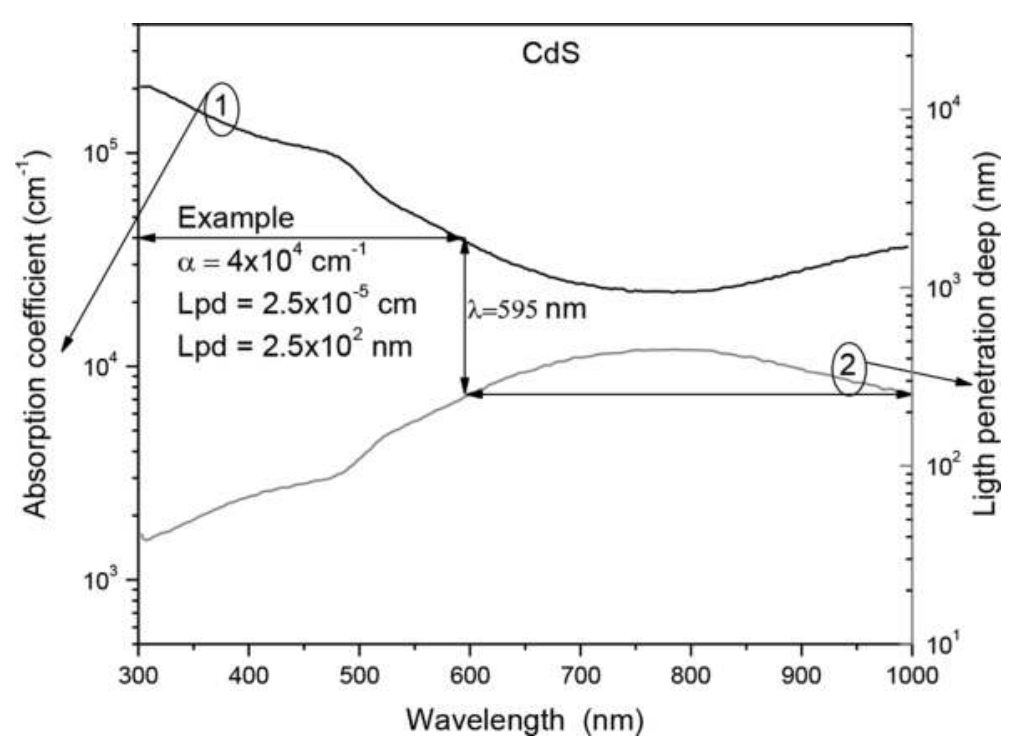

Figure 8. Absorption coefficient and light penetration deep for the CdS, this graph can be used as a design tool to determine the thickness for the CdS layer for solar cells.

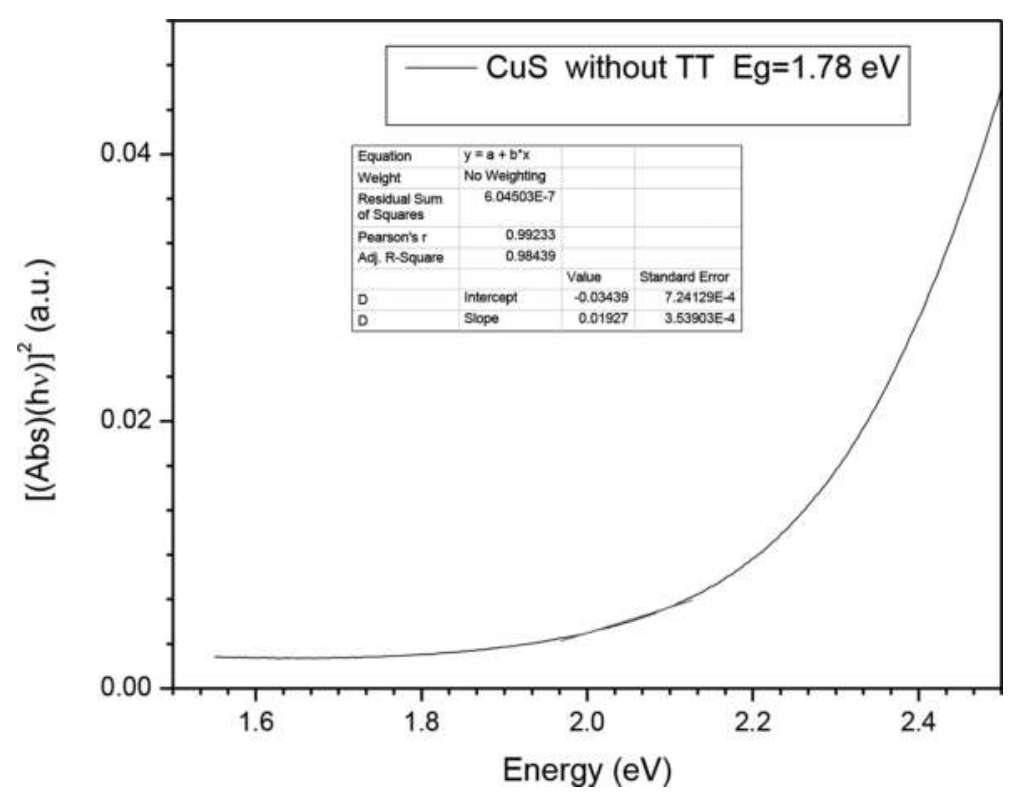

Figure 9. Band gap compute showing the region where is present the absorption edge for CuS as ground. 
thin film and as ground CuS thin film and annealed CuS thin film (as with thermal annealing as without thermal annealing). The energetic levels located in each one of the thin films are shown in Table 1 and Figure 5. Table 1 also presents the name of each chemical compound and its location.

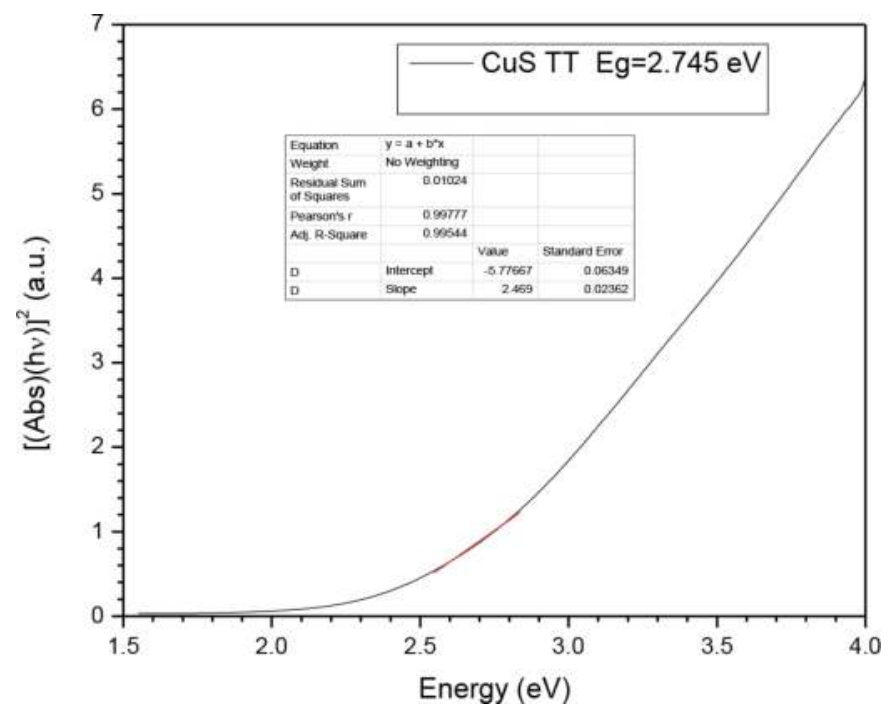

Figure 10. Band gap compute showing the region where is present the absorption edge for the CuS with thermic annealing.

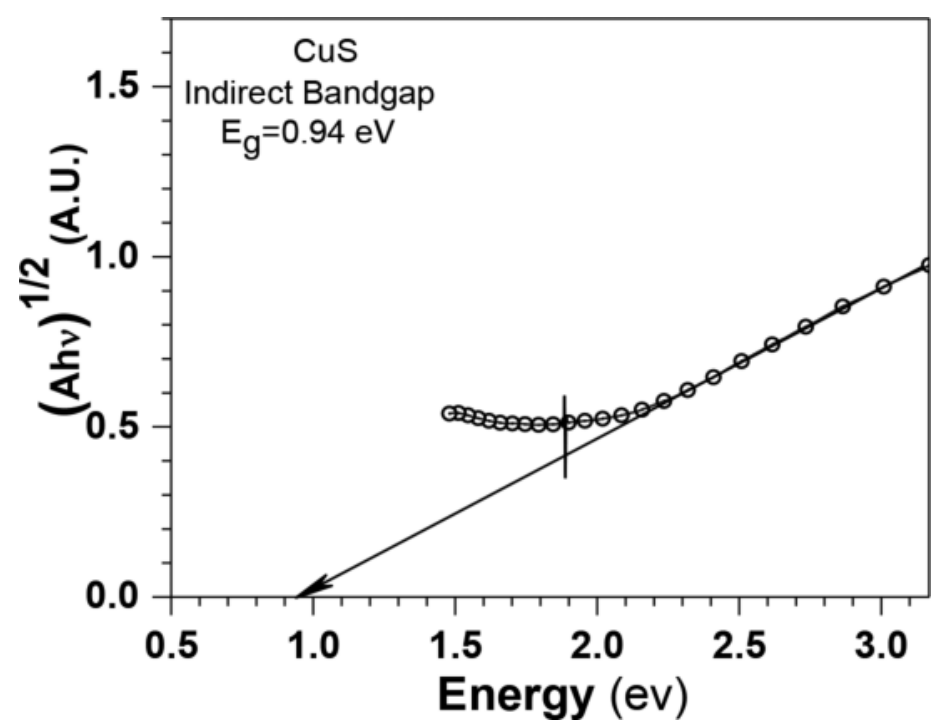

Figure 11. Indirect band gap compute for CuS as ground. 
Table 1 shows 11 peaks identified for the CdS, 10 for PbS and 13 for the CuS. All these peaks confirm the high purity of the material preparation.

On the other hand, Figure 6 depicts the absorption responses for one $\mathrm{CdS}$, one $\mathrm{PbS}$ and two $\mathrm{CuS}$ thin films. The CuS thin films correspond one to as ground film and other with thermal annealing. Reaction conditions are as follows: for CdS: reaction temperature $70^{\circ} \mathrm{C}$ and reaction time, $10 \mathrm{~min}$; for $\mathrm{PbS}$ : reaction temperature $75^{\circ} \mathrm{C}$ and reaction time $5 \mathrm{~min}$; and for as ground CuS: reaction temperature $55^{\circ} \mathrm{C}$ and reaction time $20 \mathrm{~min}$, while a replicate of $\mathrm{CuS}$ has been thermal annealed to $180^{\circ} \mathrm{C}$ for $20 \mathrm{~min}$.

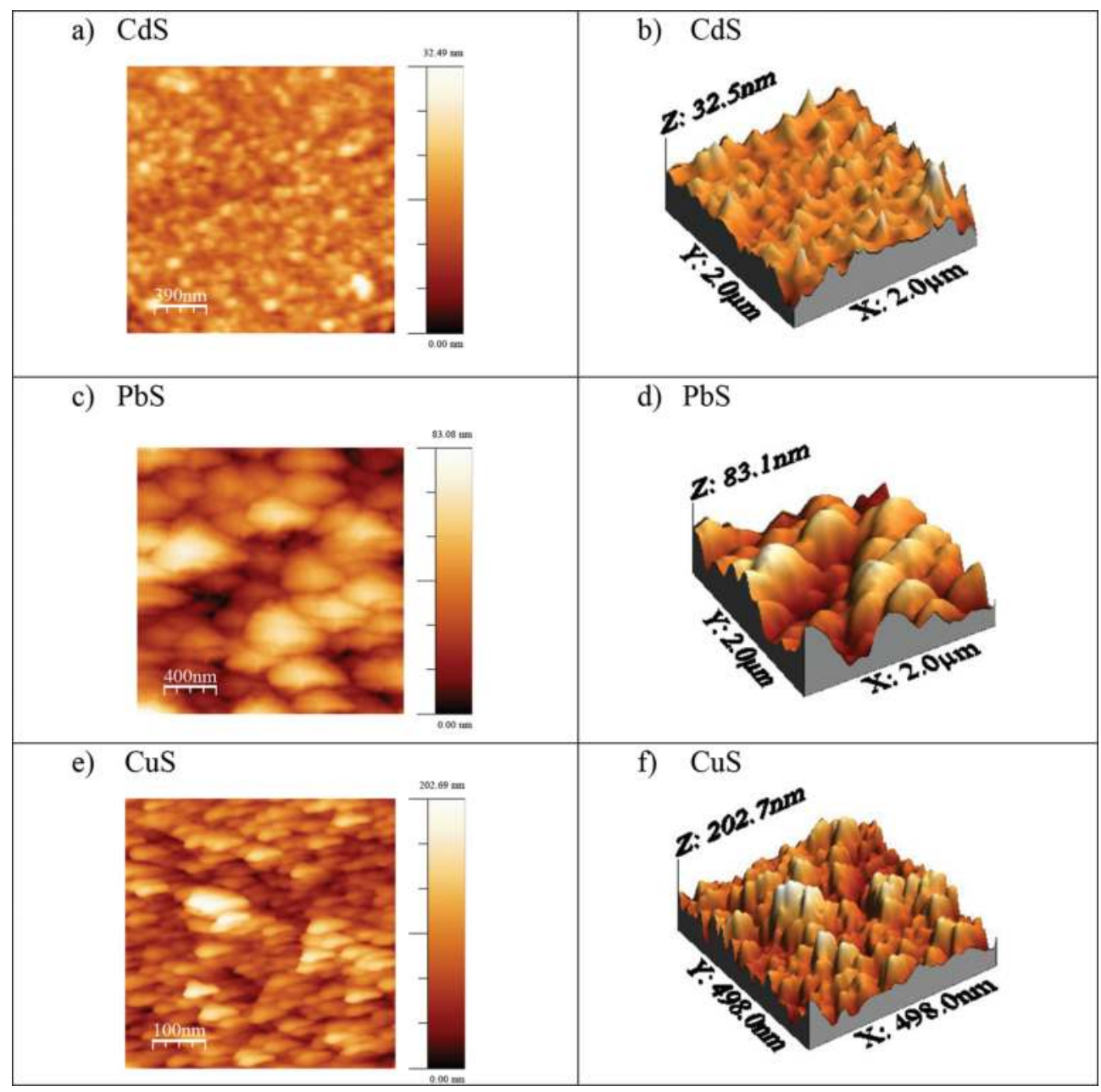

Figure 12. Images (a) and (b) show the surface profile corresponding to CdS thin film elaborated, (c) and (d) images show the corresponding PbS and (e) and (f) images show for CuS films [18]. 
Figure 7 shows the graphical calculation procedure which determines the optical direct band gap and this procedure is typically denominated by Tauc procedure. The intercept had a value of -3.67123 (a.u.), while the slope was 1.48674 (a.u./eV)

A very interesting and useful analysis is the corresponding to comparison between the absorption coefficient $\left(\mathrm{cm}^{-1}\right)$ and the light penetration deep $(\mathrm{nm})$, see Figure 8. The relationships among them are basically multiplicative inverses; for example, we choose the wavelength value of $595 \mathrm{~nm}$ and from there, the values for the absorption coefficient $(\alpha)$ and light penetration deep (Lpd) are $4 \times 10^{4} \mathrm{~cm}^{-1}$ and $2.5 \times 10^{2} \mathrm{~nm}$, respectively. This curve is important because is a good tool to solar cell designs. In this curve is possible chose the thickness to satisfy a quantity of absorption and penetration length deep.

As shown in Figure 9-Figure 11, the direct band gap value is computed for the CuS thin films obtained by chemical bath deposition, in the curve seen in Figure 9, the direct band gap is 1.78 $\mathrm{eV}$ for the $\mathrm{CuS}$ as ground, in Figure 10, the band gap is $2.74 \mathrm{eV}$ for $\mathrm{CuS}$ which is subjected at thermal annealing. The indirect band gap of $0.94 \mathrm{eV}$ for $\mathrm{CuS}$ is shown in Figure 11.

Figure 12 depicts the surface morphology of three sulfides CdS, PbS and CuS realized by AFM on square areas of $2.0 \times 2.0 \mu \mathrm{m}^{2}$ and $498 \times 498 \mu \mathrm{m}^{2}$. (a) Image shows a top view for the CdS thin film, (b) image shows a perspective view corresponding to CdS material; (c) and (d) images show the $\mathrm{PbS}$ thin films and finally, the top and perspective views of the CuS thin film are shown in the images labeled (e) and (f). The cluster size of PbS is bigger than that of CdS, which are at the same scale, while the cluster size for CuS only was appreciable for a higher magnification; anyway, the higher profile heights were found for CuS films around six times bigger than CdS.

Figure 13 depicts an SEM micrograph of PbS and the reference scale is $200 \mathrm{~nm}$ and the superficial particles have a size of approximately $70 \mathrm{~nm}$ and are presented with less frequency. The morphology of the rest of the thin film is of particles more little and tight.

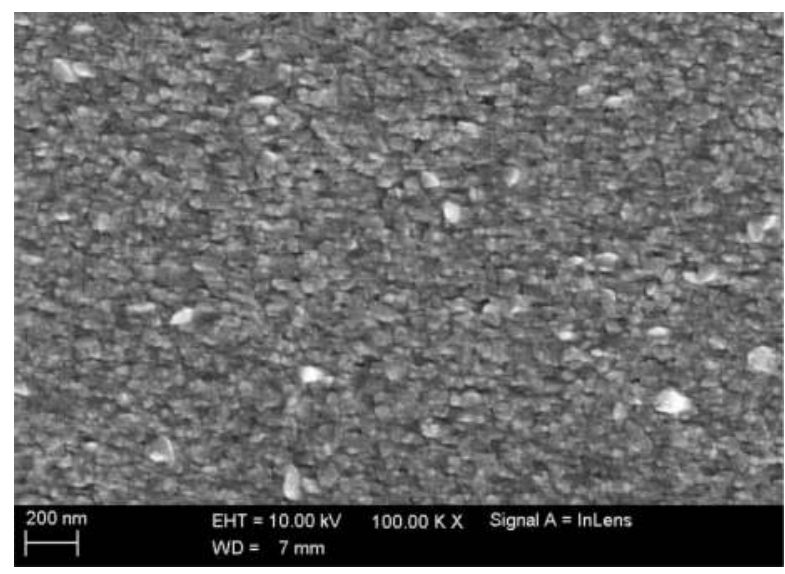

Figure 13. SEM micrograph of $\mathrm{PbS}$ thin film showing the superficial morphology for special conditions of $75^{\circ} \mathrm{C}$ for $5 \mathrm{~min}$. 


\section{Photoresponse}

The CdS was a unique material that shows the interesting behavior with time. The response should be instantaneously in a conductor however due to charge effects this is retarded in CdS and it is a dielectric material therefore the response is similar to a capacitor, when the energy is increased above of the band gap this exponential behavior is increased. Figure $\mathbf{1 4}$ shows the behavior of the photoresponse at three different wavelengths, showing a greater need for stabilization time at a wavelength close to the bandwidth.

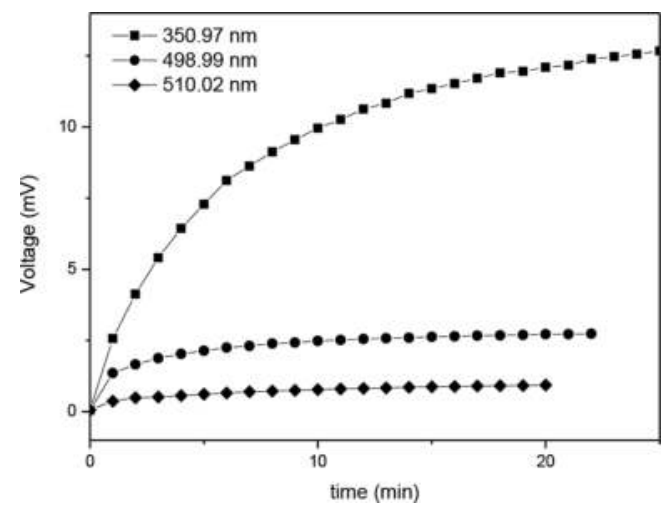

Figure 14. Response time for the CdS thin film synthetized by DBQ at $70^{\circ} \mathrm{C}$ for $10 \mathrm{~min}$ and studied at $\lambda=350.97,498.9$ and 510.02, respectively.

The graph of resistance vs. temperature for the CuS thin films with thermal annealing determines the semiconductor behavior from the slope of the curve of Figure 15. This curve is nearly linear and then it is possible fitting by a line. The minimal resistance is present at $112^{\circ} \mathrm{C}$ being $1047180 \Omega$. In this case, we can see that this curve is composed of three straight lines approximately all of these of semiconductor behavior but with different slopes (see Figure 16) [29].

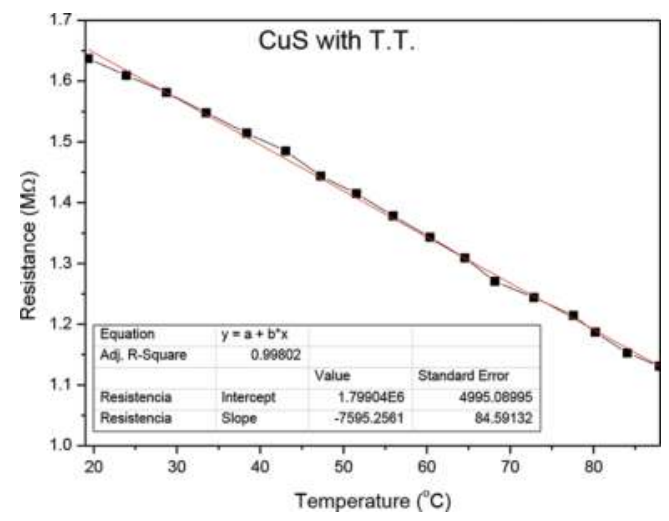

Figure 15. Linear fitting from the resistance vs. temperature of the CuS thin film with thermal annealing. 


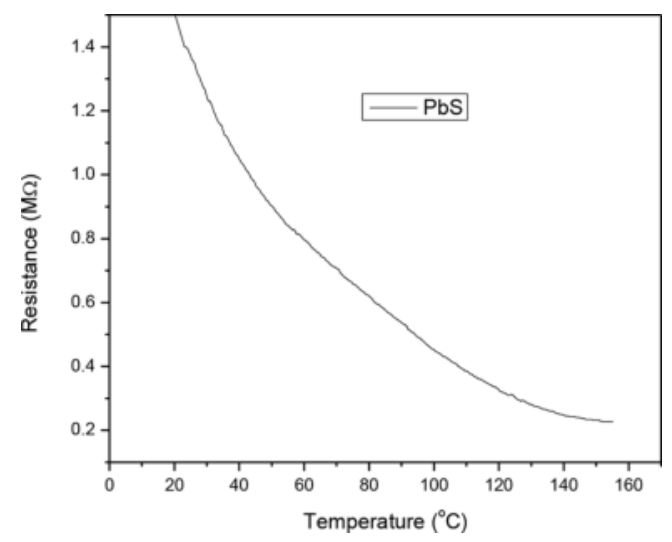

Figure 16. Nonlinear fitting from the resistance vs. temperature of the PbS thin film.

Figure 17 shows the structure of a solar cell, where on a glass substrate covered by an ITO film is deposited CdS by the aforementioned procedure the PbS is then deposited following the formula of the section (Synthesis of the thin films) and finally are Deposited silver contacts to measure the complete structure, the contacts are periodically separated by $1 \mathrm{~cm}$ as shown in this figure.

The $I-V$ curve in Figure 18 shows an on voltage that increase with the increase of the measure area because each measure is realized considering first E1 respect to ITO, after that $\mathrm{E} 1+\mathrm{E} 2=\mathrm{E} 2$ respect to ITO and so on. The measure result is shown in the curve $I-V$, which indicates that when the slope increases the resistance decreases, increasing therefore with current.

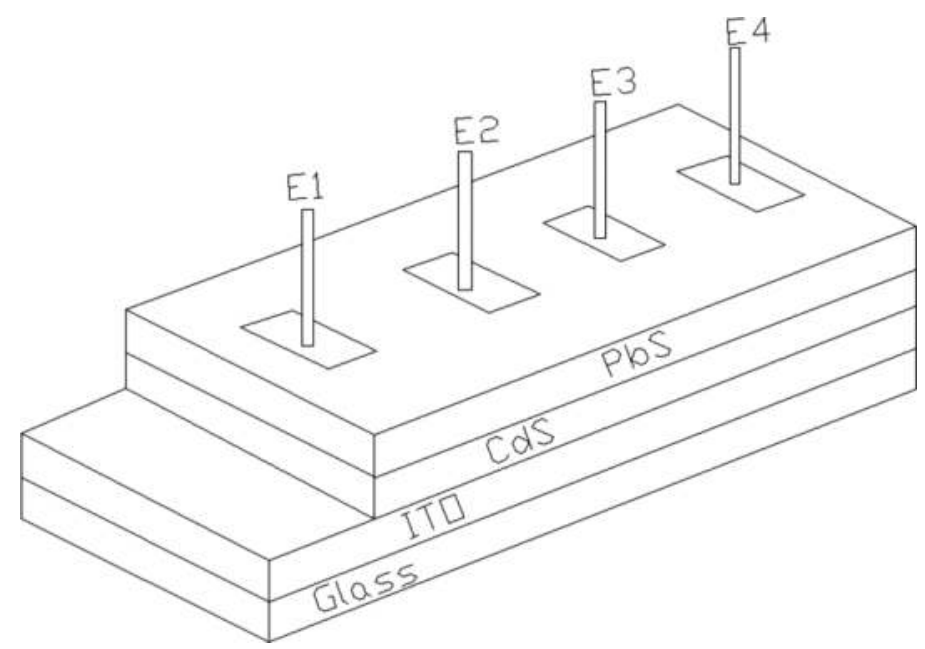

Figure 17. Three-dimensional solar cell structure showing details of front and rear contact arrangement. 


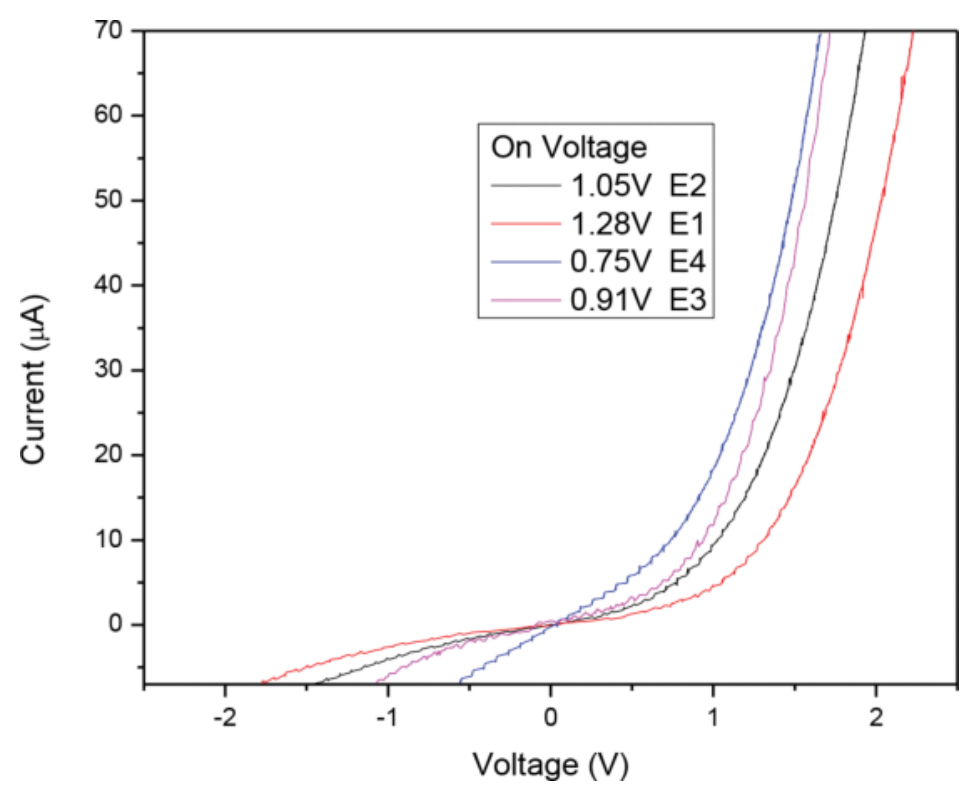

Figure 18. $I-V$ response for the example structure.

\section{Conclusions}

The main conclusion establishes that the chemical bath deposition technique is a simple and low-cost process and that it is used to obtain thin films of $\mathrm{CdS}, \mathrm{PbS}$ and $\mathrm{CuS}$ with very good homogeneity, pure enough and low cost, which can be used in wide range of applications.

CdS thin films obtained using glycine as a complexing agent presented hexagonal polycrystalline structure. The method used for PbS thin films in this work also produced a polycrystalline film but with cubic geometry. The CuS thin film was an amorphous material and weakly adhered to the substrate.

Their optical responses in the UV-vis range are according with some reported values. Some electrical and thermal tests were used on the obtained materials, In order to future applications.

\section{Acknowledgements}

We would like to thank the facilities provided by the Laboratory XPS UNISON, M.C. Roberto Mora Monroy and XRD Laboratory CINVESTAV Qro. Q.A. Martin Adelaido Hernandez Landaverde. 


\section{Author details}

Armando Gregorio Rojas Hernández* and S. Jesus Castillo

*Address all correspondence to: arojas@cifus.uson.mx

Departamento de Investigación en Física, Universidad de Sonora, Hermosillo, Sonora, Mexico

\section{References}

[1] O.R. Akhmedov, M.G. Guseinaliyev, N.A. Abdullaev, N.M. Abdullaev, S.S. Babaev, N.A. Kasumov, Optical properties of PbS thin films, Semiconductors, 2016, Volume 50, Issue 1, pp. 50-53.

[2] S. Seghaier, N. Kamoun, R. Brini, A.B. Amar, "Structural and optical properties of PbS thin films deposited by chemical bath deposition", Materials Chemistry and Physics, 2006, Volume 97, pp. 71-80.

[3] J.A. García-Valenzuela, M.R. Baez-Gaxiola, M. Sotelo-Lerma, “Chemical bath deposition of $\mathrm{PbS}$ thin films on float glass substrates using a $\mathrm{Pb}(\mathrm{CH} 3 \mathrm{COO}) 2-\mathrm{NaOH}-(\mathrm{NH} 2) 2 \mathrm{CS}-\mathrm{N}$ $(\mathrm{CH} 2 \mathrm{CH} 2 \mathrm{OH}) 3-\mathrm{CH} 3 \mathrm{CH} 2 \mathrm{OH}$ definite aqueous system and their structural, optical and electrical/photoelectrical characterization", Thin Solid Films, 2013, Volume 534, pp. 126131

[4] J.J. Valenzuela-Jauregui, R. Ramırez-Bon, A. Mendoza-Galvan, M. Sotelo-Lerma, “Optical properties of PbS thin films chemically deposited at different temperatures", Thin Solid Films, 2003, Volume 441, pp. 104-110.

[5] J.I. Pankove, Optical Processes in Semiconductors, Dover Publications Inc., New York, 1971.

[6] H. Kanazawa, S. Adachi, Optical properties of PbS, Journal Applied Physics, 1998, Volume 83, p. 5997.

[7] C.O. Mosiori, Orori, W. N. Njoroge, , O. John, Optical and Electrical Properties of Pbs Thin Films Grown by Chemically Bath Deposition [CBD] at Different Lead Concentrations, International Journal of Advanced Research in Physical Science (IJARPS), May 2014, Volume 1, Issue 1, pp. 25-32.

[8] S.V. Bhatt, M.P. Deshpande, B.H. Soni, N. Garg, S.H. Chaki, Chemical bath deposition of lead sulphide (PbS) thin film and their characterization, Solid State Phenomena, 2014, Volume, 209, pp. 111-115.

[9] F. Gödea, F. Yavuza, I.A. Karıperb, Preparation and characterization of nanocrystalline pbs thin films produced by chemical bath deposition, Acta Physica Polonica A, 2015, Volume 128, Issue 2-B, pp. B215-B218. 
[10] C.E. Pérez-garcía, R. Ramírez-bon, Y.V. Vorobiev, PbS thin films growth with CBD and PCBD techniques: A comparative study, Chalcogenide Letters, November 2015, Volume 12, Issue 11, pp. 579-588.

[11] S.M. Lee, D.H. Yeon, S.S. Chon, Y.S. Cho, Effect of double substitutions of Cd and Cu on optical band gap and electrical properties of non-colloidal PbS thin films, Journal of Alloys and Compounds, 2016, Volume 685, pp. 129-134.

[12] E.M. El-Menyawy, G.M. Mahmoud, R.S. Ibrahim, Structural, optical and electrical properties of $\mathrm{PbS}$ and PbSe quantum dot thin films, Journal of Materials Science-Materials in Electronics, 2016, Volume 27, Issue 10, pp. 10070-10077.

[13] I. E. Moreno-Cortez, A. Alvarado-Castaneda, D. F. Garcia-Gutierrez, Core-shell PEDOT: PSS-PVP nanofibers containing PbS nanoparticles through coaxial electrospinning, Synthetic Metals, 2016, Volume: 220, pp. 255-262.

[14] W. Yao, W. Qisheng, Y. Lei, Epitaxial 2D PbS nanoplates arrays with highly efficient infrared response, Advanced Materials, 2016, Volume: 28 Issue 36, pp. 8051-8057.

[15] W. Heng, Z. Guang-Mei, Z. Ji-Tao, PbS quantum dots: size, ligand dependent energy level structures and their effects on the performance of heterojunction solar cells, Journal of Inorganic Materials, 2016, Volume 31, Issue 9, pp. 915-922.

[16] M. Gilic, J. Trajic, N. Romcevic, M. Romcevic, D. V. Timotijevic, G. Stanisic, I. S. Yahia, Optical properties of CdS thin films, Optical Materials, 2013, Volume 35, Issue 5, pp. 1112-1117.

[17] K. Ravichandran, N. Nisha Banu, V. Senthamil Selvi, B. Muralidharan, T. Arun, Rectification of sulphur deficiency defect in CdS based films by introducing a novel modification in the SILAR cyclic process, Journal of Alloys and Compounds, 2016, Volume 687, pp. 402-412.

[18] N. Susha, R. J. Mathew, S. S.Nair, Tuning of optical and magnetic properties of nanostructured CdS thin films via nickel doping, Journal of Materials Science, 2016, Volume 51, Issue 23, pp. 10526-10533.

[19] M. Guo, L. Wang, Y. Xia, W. Huang, Z. Li, Enhanced photoelectrochemical properties of nano-CdS sensitized micro-nanoporous $\mathrm{TiO}_{2}$ thin films from gas/liquid interface assembly, Journal of Alloys and Compounds, 2016, Volume 684, pp. 616-623.

[20] L.V. Garcia, S.L. Loredo, S. Shaji, J.A. Aguilar Martinez, D.A. Avellaneda, T.K. Das Roya, B. Krishnana, Structure and properties of CdS thin films prepared by pulsed laser assisted chemical bath deposition, Materials Research Bulletin, 2016, Volume 83, pp. 459-467.

[21] B. Liu, R. Luo, B. Lia, J. Zhang, W. Li, L. Wu, L. Feng, J. Wu, Effects of deposition temperature and $\mathrm{CdCl}_{2}$ annealing on the $\mathrm{CdS}$ thin films prepared by pulsed laser deposition, Journal of Alloys and Compounds, 2016, Volume 654, pp. 333-339. 
[22] X. Yang, B. Liu, B. Li,, J. Zhang, W. Li, L. Wu, L. Feng, Preparation and characterization of pulsed laser deposited a novel CdS/CdSe composite window layer for CdTe thin film solar cell, Applied Surface Science, 2016, Volume 367, pp. 480-484.

[23] J. Maricheva, S. Bereznev, R. Naidu, N. Maticiuc, V. Mikli, J. Kois, Improved electrodeposition of CdS layers in presence of activating $\mathrm{H}_{2} \mathrm{SeO}_{3}$ microadditive, Materials Science in Semiconductor Processing, 2016, Volume 54, pp. 14-19.

[24] O.K. Echendu, U.S. Mbamara, K.B. Okeoma, C. Iroegbu, C.A. Madu, I.C. NdukweI., M. Dharmadasa, Effects of deposition time and post-deposition annealing on the physical and chemical properties of electrodeposited CdS thin films for solar cell application, Journal of Materials Science: Materials in Electronics, 2016, Volume 27, Issue 10, pp. 10180-10191.

[25] R.A. Harris, J.J. Terblans, Modeling the band gap of CdS quantum well structures, Physica E: Low-dimensional Systems and Nanostructures, 2016, Volume 84, pp. 415-422.

[26] S.J. Castillo, A. Apolinar-Iribe, A. de León, C. Ruvalcava-Cornejo, Optical and structural analysis of ammonia-free cooper sulphide thin films using chemical deposition method, Journal of Optoelectronics and Advanced Materials, 2011, Volume 13, Issue 10, pp. 1258 1261.

[27] R. De Marco, R. Mattrall, J. Liesegang, G. Nyberg, I. Hamilton, Analytical Chemistry, 1992, Volume 64, p. 594.

[28] I. Grozdanov, C.K. Barlingay, S.K. Dey, Materials Letters, 1995, Volume 23, p. 181.

[29] L. Saviot, B. Champagnon, E. Duval, A.I. Ekimov, Resonant low-frequency Raman scattering in CdS-doped glasses, Journal of Crystal Growth, 1998, Volumes 184-185, pp. 370373. 
